ISSN (Print) : :1412-7601

ISSN (Online) : 2654-8712

Volume 6, No.1 Maret 2020

EKONOBIS

http://www.ekonobis.unram.ac.id

\title{
Mengenal Pemikiran Old Institutional Economics (OIE) Dalam Ilmu Ekonomi Kelembagaan
}

\section{M.Firmansyah \\ Universitas Mataram ARTICLE INFO \\ Keywords : \\ Old Institutional Economics, Veblen, Commons, Mitchel and Ayres}

ABSTRACT : This article explains the Old Institutional Economics (OIE) of thoughts. The method is used by library research. There are several findings: 1). OIE was rejected classical economics thought which ignores institutional factors, like values, culture, and rule of life in economics. 2). The foundation of institutional economics came from teachers and it is students. In case, Thorstain B Veblen was the godfather of the thoughts. 3). Veblen puts forward the evolution of thought based on the social environmental conditions in which individuals live. 4). Veblen's students like Commons focused on multidisciplinary science in explaining economics, Mitchell focused on the character of behavior based on local institutions and Ayres focused on institutional change.

Kata Kunci : Ekonomi Kelembagaan Lama (OIE), Veblen, Common, Mitchel dan Ayres Lama. Metode yang digunakan dalam artikel ini adalah penelitian kepustakaan. Ada beberapa temuan artikel ini: 1). Gagasan Ekonomi Kelembagaan lama secara umum menolak pemikiran klasik yang mengabaikan faktor-faktor kelembagaan berupa nilainilai, budaya dan rule of life dalam ilmu ekonomi. 2). Peletak dasar pemikiran ekonomi kelembagaan adalah guru dan murid, di mana Thorstain B Veblen merupakan god father dari ilmu ekonomi kelembagaan. 3). Veblen mengedepankan evolusi pemikiran yang berdasar pada kondisi lingkungan sosial tempat individu hidup. 4). Pemikiran Murid-murid Veblen, yaitu Commons menitikberatkan pada multidisiplin ilmu dalam mejelaskan ilmu ekonomi, Mitchell menitikberarkan pada karakter perilaku berdasar kelembagaan lokal dan Ayres menitikberatkan pada perubahan kelembagaan.

Corresponding Author:

Alamat : Program Studi Ekonomi Pembangunan, Fakultas Ekonomi dan Bisnis, Universitas Mataram, Jln. Majapahit No. 62 Mataram.

e-mail: firmansyah@unram.ac.id 


\section{PENDAHULUAN}

Eksistensi pemikiran ekonomi Commons (1862-1945) dan Clarence kelembagaan (intitutional economics) dewasa ini menunjukan perkembangan Ayres (1891-1972). yang menakjubkan, khususnya dalam penelitian bidang ekonomi. Kata "institutional economics" di dalam mesin pencari ilmiah google scholar tidak kurang 3,9 juta artikel tersedia di sana, website jurnal ternama proquest memuat 84 ribu artikel, Sciense Direct 167 ribu artikel. Hal ini, menunjukan perhatian terhadap riset bertema ekonomi kelembagaan semakin tinggi.

Keterbatasan teori neo-klasik dalam menyertakan unsur kelembagaan menjadi sasaran kritik. Di samping itu, beberapa studi membuktikan bahwa faktor penyebab perilaku ekonomi di samping unsur ekonomi (homo economicus) juga faktor budaya, nilainilai, keorganisasian yang merupakan bagian mendasar ekonomi kelembagaan.

Artikel ini menjelaskan sejarah dan gagasan pemikiran ekonomi kelembagaan atau Old Institutional Economics (OIE) lama sebagai peletak fondasi ekonomi kelembagaan (institutional economics). OIE adalah rangkaian pemikiran guru dan murid, antara Thornstein Veblen (18571929) sebagai guru dan murid-muridnya: Wesley Mitchell (1874-1948), John

\section{PEMBAHASAN}

\section{Definisi Ekonomi Kelembagaan}

Kata kelembagaan dalam banyak literatur ditulis sebagai institution. Pengertian kelembagaan atau institution dalam ilmu ekonomi adalah aturan hidup, organisasi, kepercayaan dan norma (North, 1990) dalam kelompok manusia. Aturan hidup, organisasi, atau norma merupakan bentukan turun temurun, generasi-ke generasi (secara historis). Ekonomi kelembagaan memberi porsi penghargaan terhadap pemikiran historis sebagai rujukan gagasan kelembagaan (institusi). Memahami sejarah hidup manusia adalah rangkaian cerita dari nilai-nilai yang pernah ada. North (1990) menganggap peraturan berupa kelembagaan adalah bentuk pembatasan kehidupan manusia dalam mengatur interaksi antar sesama, sehingga aturan itu dapat berupa aturan formal maupun non-formal (North, 1990: 4), aturan resmi (kenegaraan) atau tidak resmi (kearifan lokal, awik-awik dan lainlain).

Tanpa merubah makna

sebelumnya, Schmid (2004: 2) berpandangan bahwa kelembagaan cukup mampu menggerakkan individu untuk 
melakukan apa yang mereka tidak dapat lakukan sendiri. Tampaknya Schmid (2004: 2) mengacu pada gagasan Commons, salah seorang pencetus ekonomi kelembagaan, Commons menonjolkan model aksi bersama (collective action) yang juga berarti aturan yang disepakati bersama (Milonakis dan Fine, 2009: 177).

$$
\text { Collective action sekaligus }
$$

berperan sebagai pemberi batasan baik dan buruk perilaku atau pengontrol perilaku. Aturan bersama itu telah berlaku umum (kolektif) sebagai bentuk kesepakatan bersama individu sehingga masyarakat dapat menerima, legowo sebagai pedoman kolektif dalam kehidupan mereka. Misalnya, menghormati orang tua dengan bertutur kata yang sopan merupakan aturan dan kesepakatan bersama tanpa perlu ditulis, semua mengakui dan menghormati aturan itu. Dapat dimaknai bahwa, masyarakat senantiasa diikat, dibatasi ruang geraknya untuk tidak berlaku tidak sopan terhadap orang tua. Demikian pula dengan tata cara berekonomi akan selalu dibangun berdasar kebiasaan dan norma yang diterima lingkungan.

\section{Thorstain B. Veblen Sebagai God Father}

Sebagai god father ekonomi kelembagaan, Veblen menganggap kelembagaan sebagai proses evolusi berpikir manusia, layaknya evolusi Darwin. Manusia dianggap binatang sosial, la bertindak dan bertingkahlaku tergantung lingkunganya. Darwin membangun teori tentang evolusi kelahiran (kehidupan) manusia secara fisik, sementara Veblen mengambil konsep evolusi dalam manusia berpikir, menggunakan akal dan kemudian bertingkah laku dari apa yang dipikirkannya. Entah dari mana awal pemikiran Veblen, yang pasti 1500 tahun yang lalu dalam Islam telah menjelaskan logika berpikir macam ini, bahwa lingkungan menentukan baik buruknya perilaku individu yang dianalogikan sebagai teman dengan penjual minyak wangi. Bila berteman dengan penjual minyak wangi, akan terkena dampak wangi, karena pedagang minyak wangi selalu berhubungan dengan minyak wangi. Artinya bila lingkungan baik maka baik pula individu di dalamnya, begitu pula sebaliknya.

Lebih sistematis, kelembagaan dianggap sebagai aksi kolektif yang diyakini oleh Commons sebagai rangkaian hasil berpikir individu. Selanjutnya, menghasilkan kolektifitas aturan dalam mengatur kehidupan antara mereka, baik secara eksplisit maupun implisit. Sehingga perilaku individu dibatasi oleh perilaku 
kolektif, sebagai bentuk kesepakatan bersama berdasar norma-norma, keyakinan yang berlaku turun temurun dalam masyarakat. Aturan hidup itu nampaknya tidak saja dipahami sebagai aturan bersama semata, namun terbentuknya dari aturan yang berlaku turun temurun.

Gagasan kelembagaan lebih mengedepankan pola pikir manusia yang dinamis dan pengalaman secara historis membuktikan bahwa teori yang mengabaikan pola pikir manusia sebagai penentu atau fondasi utama pembahasan teori biasanya gugur oleh jaman. Sebagai contoh bagaimana gugurnya pemikiran Robert Maltus yang menganggap manusia akan bersaing hidup dalam perebutan bahan makanan, dengannya akan terjadi kelaparan karena pertumbuhan makanan tidak sebanding dengan kerasnya laju pertumbuhan manusia.

Teori Maltus dianggap sebagai teori yang mengerikan sepanjang sejarah dan menjadi inspirasi bagi pemusnahan etnis atas dasar perebutan eksistensi kehidupan, dan tentu saja Maltus mengabaikan perkembangan pemikiran manusia dalam menciptakan kemajuan teknologi makanan, dan berbagai rekayasa di dalamnya. Pertumbuhan penduduk sejak era Maltus mengeluarkan gagasannya berlipat-lipat, namun tidak terbukti manusia kekurangan bahan pangan. Kasus kelaparan yang melanda beberapa negara karena salah urus pemerintahan bukan karena ketidaktersediaan pangan. Kritik awal Veblen tentang pemikiran sejarah Jerman karena karakternya yang non-evolusi, empirisme yang berlebihan dan kurangnya teori, namun institusionalis (ekonomi kelembagaan) memiliki banyak kesamaan dengan historicisian (paham sejarah). Ada beberapa kesamaan yang dapat disandingkan antara paham sejarah dan ekonomi kelembagaan, yaitu (Milonakis dan Fine, 2009: 159-162): Pertama keprihatinan mereka terhadap lembaga kegiatan ekonomi yang kurang efektif menyelesaikan persoalanpersoalan ekonomi dan sosial yang berkembang dalam masyarakat. Kedua, penerapan jalur interdisipliner psikologis, antropologi dan sosiologi, hal ini kontras dengan paham neo-klasik yang menganggap tunggal pemikiran ekonomi. Ketiga, ekonomi adalah ilmu historis yang mempelajari hubungan ekonomi dalam konteks sejarah. Keempat, melawan metodologis individualis. Kelima, kritik terhadap neo klasik berupa gagasan manusia adalah rasional, manusia hedonistik, yang oleh paham 
kelembagaan dianggap sebagai kalkulator petir dari kesenangan (leasure). Menurut veblen, individu merupakan mahluk sosial yang dikondisikan oleh lingkungan sosial di mana dia berada, sisi lain manusia dianggap oleh Veblen sebagai binatang sosial. Keenam, menyukai pendekatan dinamis, Veblen mengamati keseimbangan akan selalu tunduk pada normalitas atau hukum alam.

Tindakan manusia umumnya diarahkan oleh kebiasaan, unsur kepentingan dan berbagai pemikiran yang diperoleh dari berbagai rangsangan (Firmansyah et al, 2013) dan mungkin sejarah hidup. Sehingga banyak bidang ilmu yang menjelaskan arah dan pemicu tindakan manusia. Ada ungkapan seorang Commons dalam salah satu bukunya yang dicetak di tahun 1950-an, dikutip oleh Melonakis dan Fine (2009: 176): "I have never been able to think of the various social sciences as separate fields of history, political science, economics, ethics and administration"

\section{Pemikiran Commons Dan Aksi Kolektif}

Argumen Commons menegasikan bahwa ilmu ekonomi bukanlah ilmu mandiri, berdiri sendiri tanpa topangan ilmu lain. Dengan demikian belajar ilmu ekonomi sejatinya harus memberikan kesempatan yang sama terhadap ilmu lain untuk berargumen dalam ilmu ekonomi. Penekananan Commons sebenarnya tertuju pada sejarah hukum, hak properti, evolusi negara serta dampak dari evolusi negara dan organisasi serikat buruh terhadap perekonomian. Commons telah mempublikasikan beberapa karya tulis (misalnya berupa buku) di antaranya, Hukum Yayasan Kapitalisme (1924), Ekonomi Kelembagaan (1990a dan 1990b) dan Ekonomi Aksi Kolektif (1950). Bila digariskan secara umum, argumen Commons tidak jauh dari seputar peran lembaga-lembaga hukum dalam kegiatan perekonomian. Sehinga, Commons menjadikan tradisi ekonomi kelembagaan berpijak pada fondasi teori yang lebih sistematis (Hodgson, 2003).

Menurut Commons ekonomi kelembagaan merupakan bentuk model perilaku (behavioristic). Dalam hal ini Commons menekankan pada aspek kehendak aktivitas manusia. Dalam ilmu ekonomi, Common memiliki pemikiran khusus dengan mendefinisikan ekonomi sebagai ilmu perilaku yang membutuhkan analisis sebab, efek atau tujuan serta sintesis dalam sistem atau prinsip yang memiliki keterpaduan. Keterpaduan ini menghasilkan apa yang disebutnya sebagai aksi kolektif. Di mana aksi kolektif merupakan pengendalian, pembebasan 
dan perluasan aksi individu, lebih jauh aksi kolektif mengambil bentuk tabu atau larangan (sanksi) pada tindakan individu (Milonakis dan Fine, 2009: hal 177).

Pada saat tertentu sifat manusia akan dihadapkan pada persoalan kompleks yang bersumber dari kebutuhan hidup, serta persoalan lain yang kemudian muncul dalam kehidupan. Hal ini, menyebabkan ia keluar dari aturan, norma sosial yang merupakan aksi kolektif itu. Sehingga, lingkungan dapat menjadi hakim yang memberi keputusan kebersalahan akibat melanggar aturan sosial yang disepakati bersama. Aksi kolektif ini layaknya penegak hukum yang mengamati perilaku menyimpang individu.

Bagi masyarakat yang hidup berdasar agama (wahyu illahi), aksi kolektif dapat dipandang sebagai aturan yang digariskan oleh wahyu Allah SWT, Tuhan Yang Maha Esa. Mereka bersepakat bahwa aturan Allah adalah aturan kolektif bagi diri mereka untuk mengatur lalu lintas perilaku keseharian. Aturan itu merupakan bentuk kesepakatan yang tidak terbantahkan dengan meyakini bahwa aturan Allah jauh lebih sempurna, mengakomodir dua dimensi, kehidupan dunia dan saat kematian kelak. Pengabaian pada aturan ilahiah diyakini menjadi penyebab utama disharmoni kehidupan. Kecurangan dagang, korupsi dan perilaku kriminal lain dalam transaksi ekonomi merajalela karena terlanggarnya aturan kolektif tersebut.

\section{Pemikiran Mitchell Dan Peran Budaya}

Generasi ekonomi kelembagaan lama selanjutnya adalah Mitchell yang juga merupakan murid dari Veblen. Pemikiran Veblen sangat kental mempengaruhi pola pikir Mitchell. Mengikuti sang guru, Mitchell menganggap dirinya sebagai bagian dari tradisi evolusi ekonomi. Padangan Mitchel yang dikutip utuh oleh Milonakis dan Fine (2009: 182) sebagai berikut:

"Orang yang diciptakan oleh imajinasi para ekonom memang memiliki karakter tipis dan formal dibandingkan dengan pewaris mereka dari segala usia, dengan warisan yang kaya ras naluri, mewarisi konsep sosial, kekayaan serta berbagai kebiasaannya. Rasionalitasnya didapatkan dari karakter lembaga-lembaga di mana ia dibesarkan"

Pengabaian sisi atau karakter kemanusiaan secara konsisten menjadi senjata bagi pemikir ekonomi kelembagaan mengkritisi ekonomi mainstream yang terlalu fulgar 
mengabaikan peran penting manusia. Pada awalnya ilmu ekonomi adalah ilmu perilaku, sehingga seharusnya lebih jauh mengamati apa yang disebut Mitchell sebagai konsep sosial (social concept). Sosial konsep menjadi inti bahasan dari kelembagaan sosial, di mana konsep sosial dan kelembagaan mencerminkan aktivitas manusia dan aktivitas ekonomi (Milonakis dan Fine, 2009: 183). Terkait cabangcabang ilmu ekonomi yang telah eksis, Micthell sependapat dengan Schumpeter yang mengharapkan kerja sama yang erat antara teori ekonomi, sejarah ekonomi dan ekonomi terapan.

Mitchell juga mencermati ilmu ekonomi yang cenderung menggunakan metode kuantitatif sehingga menjadi kurang peduli terhadap teka-teki motif dibalik perilaku ekonomi yang terekam oleh data ekonomi. Namun, pendekatan kuantitatif hanya peduli pada tujuan dari proses akhir. Bukan berarti Mitchell meninggalkan seutuhnya metode kuantitatif, karena sepanjang karirnya sebagai salah satu pendiri biro riset ekonomi banyak menghasilkan studi-studi empiris terkait siklus bisnis, pergerakan harga dan memelopori berbagai analisis statistik lainnya.

\section{Ayres Dan Perubahan Kelembagaan}

Pemikir pamungkas generasi ekonomi kelembagaan lama adalah Clarence Ayres. Ayres merupakan generasi utama dan terakhir dari paham ekonomi kelembagaan lama. Dia hadir memperbaiki bentuk keseimbangan antar teori dengan penjelasan, selanjutnya menggambarkan hubungan antara institusionalisme dan empirisme. Ayres menganggap bahwa studi empiris adalah pelengkap teori kelembagaan. Jalur pemikiran Ayres dalam ekonomi kelembagaan dapat dibaca dalam bukunya yang berjudul Teori Kemajuan Ekonomi (1962), sebagai sub judul buku itu secara terpisah memuat studi tentang dasar-dasar pembangunan ekonomi dan perubahan budaya (culture change) yang merupakan fondasi ekonomi kelembagaan lama.

Segaris dengan pendahulunya, Ayres menganggap bahwa mengamati perilaku ekonomi tidak dapat an sich dilihat dari sisi manusia sebagai motif perorangan melainkan termanifestasi dalam diri manusia sebagai fenomena sosial. Sehingga yang perlu diamati adalah bagaimana kekuatan sosial, interaksi sosial dalam berprilaku berdasarkan lingkungan. Mengikuti jejak Veblen, Ayres menganggap interaksi antara lembaga dan 
teknologi sebagai sumber prinsip dasar analitis, tujuannya untuk mempelajari ekonomi secara lebih mendalam. Menurut Ayres, kemajuan teknologi merupakan penggerak perubahan budaya dan menjadi bagian dari perubahan kelembagaan tersebut. Berbeda dengan Veblen, Ayres lebih mempertimbangkan naluri manusia dan kecenderungan perilaku akibat kemajuan teknologi. Dengannya teknologi akan mencakup semua kegiatan manusia yang melibatkan penggunaan alat-alat.

Kondisi yang diungkap Ayres sangat dapat pahami beberapa tahun terakhir, di mana teknologi telah merubah banyak perilaku, baik itu bersifat positif maupun negatif. Lyotard yang merupakan profesor filsafat estetika pada Universitas Paris De Vincennes dalam bukunya bertajuk laporan penelitian post moderenisme menjelaskan bahwa transformasi masyarakat yang terkomputerisasi lebih terbuka, majemuk, plural dan demokratis. Bahkan Lyotard menganggap kebenaran yang dibawa oleh narasi-narasi besar (grand narrative) moderenisme sebagai metanarasi telah kehilangan makna (Lyotard, 2009: 272) akibat teknologi informasi. Padahal metanarasi merupakan bentuk retorika filsafat.
Dalam konteks perilaku ekonomi, teknologi informasi dalam hal ini media televisi turut andil mempromosikan materialisme, di mana penonton berat televisi $^{1}$ akan mengarah pada materialisme, yang pada giliranya kepuasan hidup menjadi berkurang (Buroughs et al , 2002). Media televisi menayangkan berbagai aspek yang menggambarkan sikap dan sifat materialistis, yang memaksa individu menaikkan standar kehidupan, sikap materialis memaksa individu tersebut meningkatkan konsumsi, karena ketiadaan materi selanjutnya meningkatkan hutang dan upaya mengurangi konsumsi adalah berat, di sinilah kepuasan hidup yang menjadi berkurang akibat materialisme(Buroughs et al, 2002; Atay et al, 2010).

Pengabaian sisi budaya sebagai aturan hidup dapat ditemukan di mana-mana. Karakteristik budaya yang unik hilang seperti ditelan bumi, tergantikan oleh budaya baru yang dibawa media teknologi. Hal ini dibuktikan dengan transformasi beberapa bidang kehidupan yang disesuaikan dengan teknologi. Misalnya, tidak sedikit buruh tani beralih pekerjaan menjadi tukang ojek karena bersentuhan dengan teknologi (sepeda 
motor), perubahan pola konsumsi perilaku manusia terbentuk dari (makanan) dan berpakain masyarakat lingkungan di mana mereka hidup dan yang disesuaikan dengan trend kebaratdibesarkan sehingga kelembagaan dapat baratan, yang disebut westernisasi atau bersumber dari budaya dan kebiasaan Amerikanisasi, dalam aspek tertentu sehari-hari. Veblen mengedepankan seringkali merusak tatanan (kesepakatan) sosial yang secara kolektif merupakan kelembagaan itu sendiri dalam bentuk etika dan etiket.

\section{KESIMPULAN}

Ekonomi kelembagaan hadir sebagai gagasan yang menolak pemikiran klasik yang mengabaikan faktor-faktor kelembagaan (nilai-nilai, budaya dan rule evolusi pemikiran yang berdasar pada kondisi lingkungan sosial tempat individu hidup, Commons menitikberatkan pada multidisiplin ilmu dalam mejelaskan ilmu ekonomi, Mitchell menitikberarkan pada karakter perilaku berdasar kelembagaan lokal dan Ayres menitikberatkan pada perubahan kelembagaan. desa. of life) dalam aktifitas ekonomi. Pemikir ekonomi kelembagaan percaya bahwa

\section{DAFTAR PUSTAKA}

Atay, Eda G, Joseph S, Melika H dan Muris Č, 2010. Influence Of Materialism On Life Satisfaction. Vol. XXII (2010), br. 2, str. 151-166

Burroughs, J E, L. J. Shrum, Rutgers, Rindfleisch, A, 2002. Does Television Viewing Promote Materialsm? Cultivating American Perceptions of the Good Life. Advances in Consumer Research (Volume 29).

Firmansyah, M; Suman, A; Manzilati, A dan Susilo. 2012. Perdebatan Teori Rasionalitas dalam Menjelaskan Terbentuknya Biaya Transaksi pada Seleksi Pegawai Negeri. Jurnal Ekonomi dan Pembangunan Indonesia. Vol, 13 No. 1

Hodgson, G, M, 2003. John R Commons and the Fondation of Institutional Economics. Journal of Economics Issues. Vol.XXXVII. No.3 September North, D. C, 1990. Institutions, Institutional Change And Economic Performance. Cambridge: Cambridge University Press 
$\mid 46$ M.Firmansyah/Mengenal Pemikiran Old Institution Economics (OIE)...

Schmid, A.A, 2004. Conflic and Cooperation: Institutional and Behavioral Economics. USA: Blackwell Publishing

Milonakis, D., \& Fine, B, 2009. From Political Economics to Economics: Method,the Social and the Historical in the Evolution of Economic Theory. London \& New York: Routladge Lyotard, Jean-Francois. 2009. The Post Modern Condition: A Report on Knowladge. Elyati, DV (Penerjemah). Kondisi Post Modern: Suatu laporan Mengenai Pengetahuan. Surabaya. Selasar Publishing 